\title{
FOURTH ANNUAL GENERAL MEETING
}

\section{MINUTES}

THE Fourth Annual General Meeting of the Severn Wildfowl Trust was held at the Royal Society of Arts, 6, John Adam Street, Adelphi, London, W.C.2, on Wednesday, 28th March, 1951. The President, Field-Marshal Lord Alanbrooke, was in the chair. The Minutes of the Third Annual General Meeting, having been circulated to Members in the printed Report, were taken as read and signed by the President.

The Minutes of the Extraordinary General Meeting, held at Market Harborough in the Narrow Boat, Beatrice, on 16th August, 1950, were read by the Hon. Secretary and signed by the President.

The adoption of the Report of the Council together with the Balance Sheet and Accounts for 1950 (which had been circulated to Members in printed form), was proposed by the President, seconded by the Director, and carried unanimously.

The re-election of the following retiring Council Members was proposed by Mr. Keith Miller Jones and seconded by the Hon. Secretary, Mr. Michael Bratby : Guy Benson, Esq. ; R. A. H. Coombes, Esq. ; C. T. Dalgety, Esq. ; H. H. Davis, Esq. ; James Fisher, Esq. The motion was carried.

The re-election of the officers en bloc (as shown on page 2) was proposed by Major R. C. R. M. Clarke, seconded by Mr. G. T. Wilkins, and carried unanimously.

The re-election of Messrs. S. J. Dudbridge \& Sons of 8, Lansdown, Stroud, was proposed by the Treasurer, Sir Archibald Jamieson, seconded by the Hon. Secretary, Mr. Michael Bratby, and carried unanimously.

A glowing tribute to the work of the Trust was paid from the body of the hall by Mr. H. K. Hallam, who suggested that Members should be asked to pay for their Annual Reports in view of the high cost of these publications. The Director replied that the Council would consider this matter, but drew attention to the fact that a profit had been made on the sale to non-members of the first two Reports. More general support appeared to be given, however, to a plea that the Reports should continue to be free to Members, even if it should necessitate the increase of the subscription.

Mr. J. S. Gordon-Clark asked whether it would be possible to have a separate enclosure at the New Grounds for the British Waterfowl. The Director replied that this had been considered before, and explained the very great difficulties of keeping all the British species in one pen at present. British geese, for example, are kept in all the pens and even then there is scarcely enough grass for them all. To confine them to one pen would therefore be quite impossible. Another point was that many ornithologists particularly liked to be able simultaneously to compare related birds from, say, Britain and America, side by side in the same pen. He said that as soon as the Trust had acquired more ground, which it hoped to be able to do shortly, a special collection of British species only would be formed in one pen.

After the meeting, the Director showed his colour films of the Decoy and Wild Geese at the New Grounds, and of the Trust's Rocket-netting Expeditions.

Proceedings then terminated. 
THE SEVERN WILDFOWL TRUST

INCOME AND EXPENDITURE ACCOUNT FOR THE YEAR ENDED 31st DECEMBER, 1950

\section{EXPENDITURE}

To Rent, Rates and Insurance

Wages and National Insurance

Food for Waterfowl

"Purchases and Transport of Wildfowl and Eggs

Purchases of Hens for Sitting

Carriage on Birds sold

Materials (Wood for Observation Huts, "Wire Netting.

Coops, etc.)...

Miscellaneous

"Staff Travelling Expenses

"Telephone

Printing and Stationery-General

Printing of Christmas Cards

"Bank Charges

"Office Expenses, Postages, etc.

"Narrow Boat, Beatrice, Running Expenses

Land Rover Expenses

"Legal Charges re Headquarters' Cottage

Legal Charges re Lease and Licence

New Engine and Repairs to Narrow Boat

Mower and Roller

Public Conveniences

Surfacing Road

New Enclosures

"Hut and Garage

Water Supply

"Repairs to Headquarters' Cottage

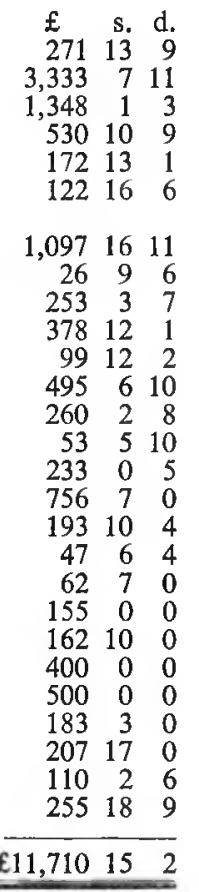

\section{INCOME}

By Subscription

", Donations

"Sale of First Annual Report

"Sale of Surplus Waterfowl

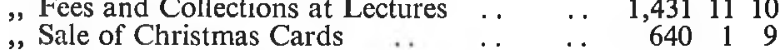

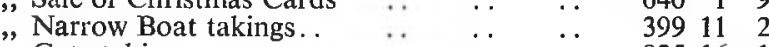

$\cdots \quad 82516 \quad 1$

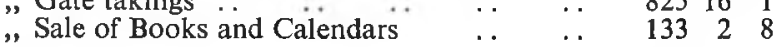

"Special Donations for Development

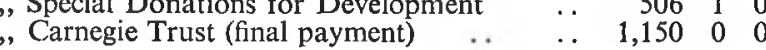

", Sale of Second Annual Report

$\begin{array}{lll}f & \text { s. } & \text { d. } \\ 3,997 & 11 & 3\end{array}$

288136

,, Sale of 'Key to Wildfowl of the World' .. $\quad 24917 \quad 3$

$1,113 \quad 0 \quad 8$

$\begin{array}{lll}8,676 & 2 & 7\end{array}$

$\begin{array}{llll}1,656 & 1 & 0 & \frac{2}{2}\end{array}$

$\begin{array}{lllll}1,362 & 17 & 11\end{array}$

11,69516

Balance, being Excess of Expenditure over

Income

$\begin{array}{lll}15 & 13 & 8\end{array}$ 
THE SEVERN WILDFOWL TRUST

BALANCE SHEET-31st DECEMBER, 1950

\section{LIABILITIES}

Sundry Creditors and Subscriptions paid in advance ..

Loan Accounts :-

Mr. Peter Scott Mr. J. H. Bevan

Reserve Account :Grant from Pilgrim Trust Balance, 31 st December, 1949

Add Increase in Valuation of Assets :Valuation, 31st December, 1950 3ist December

7,769196

Less Excess of Expenditure over Income for the

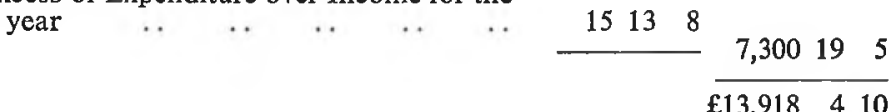$$
\begin{array}{lll}
1,072 & 0 & 6
\end{array}
$$

s. d. $\quad$ s. d. $\begin{array}{lll}617 & 5 & 5\end{array}$

$500 \quad 0 \quad 0$ $500 \quad 0 \quad 0$ $1,000 \quad 0 \quad 0$ $5,000 \quad 0 \quad 0$

1513

\section{ASSETS}

Waterfowl, at valuation . Land Rover, at valuation

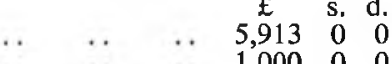
000 - 00 Coops, Hen Houses, Scythes, Trailers, etc., at

$$
\begin{array}{llllllll}
. & . & . & & . & 1,489 & 0 & 0
\end{array}
$$

Sundry Debtors 1621610 Cash at Bank

Westminster Bank Ltd., No. 1 Account Ditto, No. 3 Account ..

Lloyds Bank Ltd.

$\begin{array}{rrrr}\text {. } & 3,437 & 14 & 6 \\ . & 1,369 & 16 & 11\end{array}$

991011 4,9072420

We have examined the above Balance Sheet of The Severn Wildfowl Trust, dated 31 st December, 1950, together with the accompanying Income and Expenditure Account, with the Books and Vouchers of the Trust, and certify them to be in accordance therewith.

Stroud, Glos.

26th February, 1951

(Signed) S. J. DUDBRIDGE \& SONS,

Auditors. 


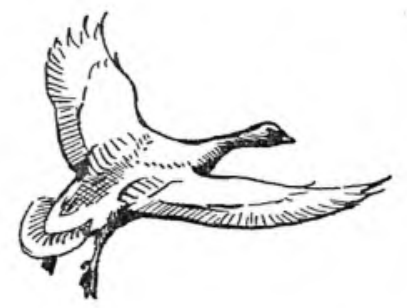

\section{ANNUAL DINNER}

After the Annual General Meeting a Dinner was held for Members and their guests at the Charing Cross Hotel. The following were present :

Miss C. M. Acland, R. F. Aickman, Mrs. R. F. Aickman, Field-Marshal Lord Alanbrooke, D. W. Allen and guest, G. Atkinson-Willes, J. S. Bain and guest, Miss J. S. Bayley and two guests, Guy Benson, Lady Violet Benson, Michael Bratby, Major F. E. Briscoe and guest, Mrs. J. Cahn, J. W. A. Calver and guest, Lt.-Gen. Sir Adrian Carton de Wiart, J. Christmas, J. C. Christopherson and guest, J. W. Clayton and guest, Edwin Cohen, Mrs. E. Cohen, Miss J. Cohen, M. Thompson Coon, Mrs. M. Thompson Coon, J. Cox, Miss Crone, Capt. C. N. E. Currey, Mrs. C. N. E. Currey, Miss S. Sinclair Davidson, Miss R. Sinclair Davidson, J. C. Davis and guest, Dr. J. Y. Dent and guest, J. R. East, J. O. d'Eath, Humphrey Ellis, Dr. N. B. Farman and guest, James Fisher, R. S. Fitter, Miss E. Forster, G. B. Gooch and two guests, Frank Grant, Mrs. F. Grant, Miss R. M. Haines, H. K. Hallam, Mrs. H. K. Hallam, Mrs. ap Hodge, Kenneth Horne, Mrs. K. Horne, Dr. M. J. Ingram, Mrs. M. J. Ingram, T. Ingram, Sir Archibald Jamieson, Major D. Jamieson, J. A. J. Jamieson, E. Lloyd Johnstone, Miss Barbara Jones, Major Laurence Jones, Mr. Miller Jones, Mrs. Miller Jones, Terry Jones, J. F. Keeble, Mrs. Rait Kerr, Miss M. Kirke, E. N. Kitcat, Major M. Knight, Mrs. M. Knight, C. Vaughan Lee, Mrs. C. Vaughan Lee, Lt.-Col. G. Lomer, Mrs. G. Lomer, C. F. Lundvall, Major E. H. Lynn-Allen, Miss V. Maxse, Hon. Ewen Montagu, L. Hugh Newman, Mrs. L. H. Newman, E. M. Nicholson, W. K. Oliver, T. L. Outhwaite, Lord Geoffrey Percy, J. M. Reakes-Williams, Miss B. M. Robbins and guest, J. A. S. Russell, Duke of Rutland, E. A. Scholes, Peter Scott, K. Shackleton, L. Spinks, Mrs. L. Spinks, Miss M. Spinks, Brig. H. M. Stanford, Miss P. Talbot-Ponsonby, Miss J. Tate, Major Tapp, Mrs. Tapp, Miss P. Townsend and guest, Vice-Admiral J. W. A. Waller and guest, Mrs. W. Boyd Watt, B. T. Whinney, A. Whitlock, G. T. Wilkins, Mrs. G. T. Wilkins, C. de Worms, B. A. Young.

The Toast List was as follows:

H.M. The King.

Proposed by the President, Field-Marshal the Rt. Hon the Viscount Alanbrooke, K.G., G.C.B., O.M., D.S.O.

The Severn Wildfowl Trust.

Proposed by Humphrey Ellis, Esq.

Reply by the Hon. Ewen Montagu, O.B.E., K.C.

The Guests.

Proposed by Lt.-General Sir Adrian Carton de Wiart, V.C., K.B.E., C.B., C.M.G., D.S.O.

Reply by Kenneth Horne, Esq. 


\section{OBITUARY}

The Trust, in common with all British ornithology, suffered grievous loss in the death of B. W. Tucker, who had been a member of the Council since its very earliest days. Although illness had prevented his attendance at recent meetings his advice was of the greatest benefit to the Trust, and the support of so eminent an ornithologist gave great encouragement in the early and formative years.

The Council has also noted with deep regret the deaths (notified since the last issue of the Annual Report) of the following members:
Miss N. E. Batty
E. W. Hendy

Brigadier F. W. Bewsher C.B.E., Miss K. M. Hughes D.S.O., M.C.

A. W. W. Brown

H. A. Calnan

G. Clinton Baker

Brigadier E. F. Davies, D.S.O., M.C.

His Grace the Duke of Devonshire, K.G.

Miss T. Fisher-Smith

Mrs. A. Graham

D. G. Hancock

Major W. Harker
W. J. Jones

G. G. Lydiard

J. M. Macmillan

R. Mason

P. F. Mountcastle

Brigadier-General W. L. Osborn, C.B., C.M.G., D.S.O.

George Bernard Shaw

Mrs. Edgar Smith

R. E. Stuart

Mrs. A. M. Vaughan-Hughes

J. C. Wigham

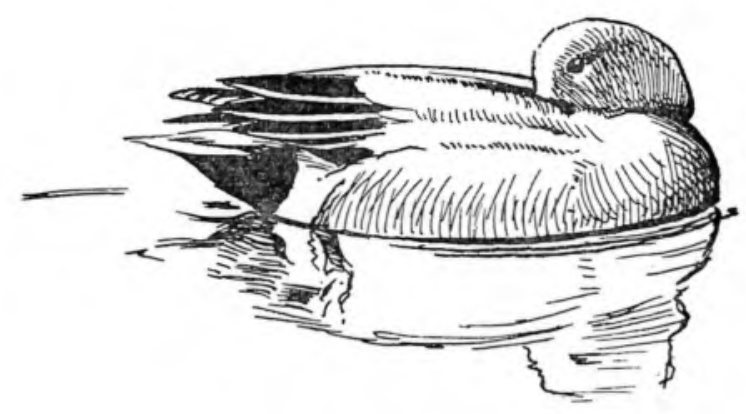




\section{MEMBERSHIP}

\section{Members}

Annual subscription 1 guinea. Free access to pens and to observation huts. May bring one guest. One copy of Annual Report. Periodical Bulletins.

\section{Associates}

Annual subscription 5s. Free access to pens and to observation huts. No copy of Report, but receive periodical Bulletins.

\section{Corporate Membership}

Annual subscription (minimum 1 guinea) 1s. each up to 50 members of Corporate body, $9 \mathrm{~d}$. each up to $100,6 \mathrm{~d}$. each above 100 . For those under 16, 9d., 6d. and 4 d. respectively. Free access to pens and to observation huts, but only in parties of not less than 10 . Not before 2 p.m. on Sundays. One copy of Annual Report and periodical Bulletins for each Corporate body. (This membership is open only to Schools, Universities, Youth Clubs, and Teachers' Training Colleges.)

\section{Parish Members}

Annual subscription 2s. 6d. Free access to pens only, but not on Sunday mornings. May bring a guest. Receive periodical Bulletins. (This membership is only open to those residing in the Parish of Slimbridge.)

\section{General Public}

Admitted to the pens only, at 2s. (children under 16, 6d.), but not before 2 p.m. on Sundays. The enclosures are open from 9 a.m. till sundown every day of the week with the exception of Sunday mornings, which are reserved for Members only.

\section{Gift Membership Tokens}

These can be purchased and given as Christmas or birthday presents. They make the recipient a Member of the Trust for a year with full facilities and a free copy of the Annual Report.

\section{Accommodation}

Hostel accommodation is available at reasonable rates for visitors, whether Members or not, on board the converted canal boat, Beatrice, which lies a few hundred yards from the Headquarters.

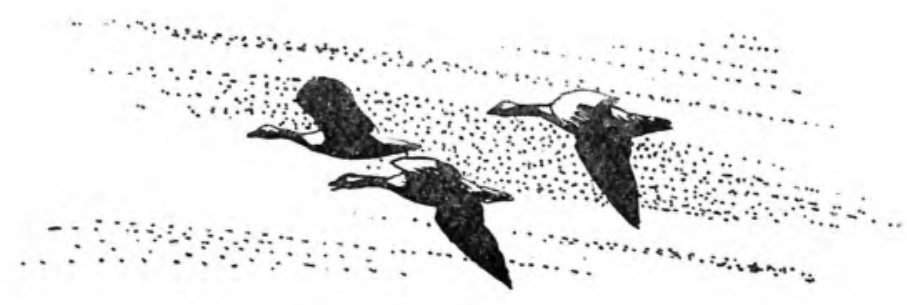

